\title{
Correction to: A new species of Xenoturbella from the western Pacific Ocean and the evolution of Xenoturbella
}

\author{
Hiroaki Nakano ${ }^{*}$, Hideyuki Miyazawa ${ }^{1}$, Akiteru Maeno ${ }^{2}$, Toshihiko Shiroishi ${ }^{2}$, Keiichi Kakui ${ }^{3}$, Ryo Koyanagi ${ }^{4}$ \\ Miyuki Kanda ${ }^{4}$, Noriyuki Satoh ${ }^{5}$, Akihito Omori ${ }^{6,7}$ and Hisanori Kohtsuka ${ }^{6}$
}

\section{Correction}

After publication of Nakano et al. (2017) [1], the authors became aware of the fact that the new species-group name erected for the two specimens of a Japanese xenoturbellid species in the article is not available because Nakano et al. (2017) [1] does not meet the requirement of the amendment of Article 8.5.3 of the International Code of Zoological Nomenclature (the Code) [2]. The authors therefore describe the two xenoturbellids as a new species again in this correction article. Methods for morphological observation, DNA extraction and sequencing were as described in Nakano et al. (2017) [1]. The holotype and paratype specimens are deposited in the National Museum of Nature and Science, Tsukuba (NSMT), Japan. The DNA sequences obtained were deposited in the International Nucleotide Sequence Database (INSD).

Genus Xenoturbella Westblad, 1949 [3]

Xenoturbella japonica sp. nov.

http://zoobank.org/6C4EA6F8-8AC1-4511-A59B-BCB 60729A85A

(Figs. 1-3, Additional files 1-3 in Nakano et al. (2017) [1])

Etymology. Named for the locality where the specimens were collected.

Holotype. NSMT-Xe 2, female (Figs. 1, 3, Additional files 1, 2 in Nakano et al. (2017) [1]), off Jogashima, Miura, Kanagawa, Japan, $35^{\circ} 06.93^{\prime \prime} \mathrm{N} 139^{\circ} 33.72^{\prime \prime}$ E to $35^{\circ} 06.95^{\prime \prime} \mathrm{N}$ 139³3.33" E, 380-554 m depth, December 9th, 2015.

Paratype. NSMT-Xe 1, juvenile, sex unknown (Figs. 2, 3, Additional files 1, 3 in Nakano et al. (2017) [1]), Sanriku coast, Iwate, Japan, $39^{\circ} 37.86^{\prime \prime} \mathrm{N} 142^{\circ} 18.22^{\prime \prime} \mathrm{E}$ to $39^{\circ} 37$.

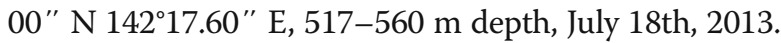

Description of female. Based on holotype. Body $5.3 \mathrm{~cm}$ in length; pale orange with coloration getting darker

\footnotetext{
* Correspondence: h.nakano@shimoda.tsukuba.ac.jp

${ }^{1}$ Shimoda Marine Research Center, University of Tsukuba, 5-10-1, Shimoda,

Shizuoka 415-0025, Japan

Full list of author information is available at the end of the article
}

toward the anterior. In live specimens, muscles hold the dorsal body wall in a W-shape (three ridges and two troughs). Body shape actively changes by contracting and elongating when alive. Ring furrow and side furrow are present. Ventral mouth present, oval-shaped, just anterior to ring furrow. Glandular network present over ventral surface, starting near anterior tip of body and ending just in front of ring furrow. Internally, body wall with epidermis, circular and longitudinal muscles, parenchyma and gastrodermis present. Oocytes present within intestine. Statocyst situated near anterior tip of body, just inside side furrow.

Description of juvenile. Based on paratype. Similar to female, but differs as follows: body $1.1 \mathrm{~cm}$ in length; pale orange in color; dorsal body surface in live specimen smooth, lacking longitudinal ridges and troughs, similar to that of $X$. bocki; gametes not observed. Ventral glandular network not detected externally, but observed with microCT imaging.

Genetic information. Whole mitochondrial genome sequences (15,244 bp in holotype; $15,249 \mathrm{bp}$ in paratype) and partial Histone $\mathrm{H} 3$ gene sequences (346 bp in holotype; $413 \mathrm{bp}$ in paratype) were determined and deposited as INSD accession numbers LC228486, LC228485, LC228579 and LC228578, respectively.

Remarks. The same species name presented in Nakano et al. (2017) [1] is nomen nudum as the publication does not meet the requirement of the amendment of Article 8.5.3 of the Code [2]. The present erratum fully meets the amended provisions of the Code, and thus this work makes the specific name japonica in the combination of Xenoturbella japonica available.

\section{Acknowledgements}

The authors would like to thank Takafumi Nakano for discussions concerning this erratum. 


\section{Author details}

'Shimoda Marine Research Center, University of Tsukuba, 5-10-1, Shimoda, Shizuoka 415-0025, Japan. ${ }^{2}$ Mammalian Genetics Laboratory, National Institute of Genetics, 1111 Yata, Mishima, Shizuoka 411-8540, Japan. ${ }^{3}$ Faculty of Science, Hokkaido University, N10 W8, Kita-ku, Sapporo, Hokkaido 060-0810, Japan. ${ }^{4}$ DNA Sequencing Section, Okinawa Institute of Science and Technology Graduate University, Onna, Okinawa 904-0495, Japan. ${ }^{5}$ Marine Genomics Unit, Okinawa Institute of Science and Technology Graduate University, Onna, Okinawa 904-0495, Japan. ${ }^{6}$ Misaki Marine Biological Station, The University of Tokyo, 1024 Koajiro, Misaki, Miura, Kanagawa 238-0225, Japan. ${ }^{7}$ Present address: Sado Marine Biological Station, Faculty of Science, Niigata University, Sado, Niigata 952-2135, Japan.

Received: 26 December 2017 Accepted: 8 May 2018

Published online: 07 June 2018

\section{Reference}

1. Nakano, et al. A new species of Xenoturbella from the western Pacific Ocean and the evolution of Xenoturbella. BMC Evol Biol. 2017;17:245.

2. International Commission of Zoological Nomenclature. Amendment of Articles 8, 9, 10, 21 and 78 of the International Code of Zoological Nomenclature to expand and refine methods of publication. Bull Zool Nomencl. 2012;69:161-9. https://doi.org/10.21805/bzn.v.69i3a8.

3. Westblad E. Xenoturbella bocki n.g, n.sp, a peculiar, primitive turbellarian type. Ark Zool. 1949;1:3-29.

\section{Ready to submit your research? Choose BMC and benefit from:}

- fast, convenient online submission

- thorough peer review by experienced researchers in your field

- rapid publication on acceptance

- support for research data, including large and complex data types

- gold Open Access which fosters wider collaboration and increased citations

- maximum visibility for your research: over $100 \mathrm{M}$ website views per year

At BMC, research is always in progress.

Learn more biomedcentral.com/submissions 